
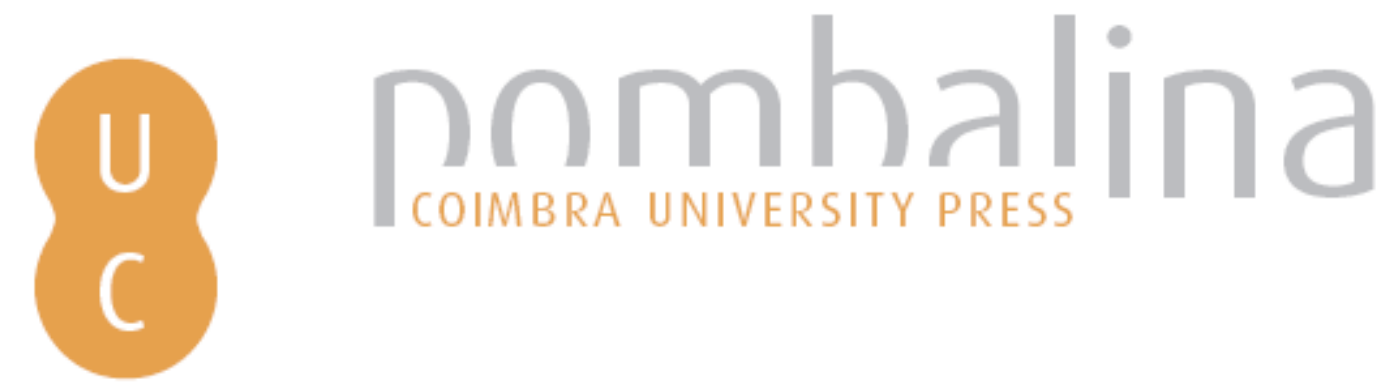

Influence of early stressful life events on the future expectancy changes and current addictions in homeless people

Autor(es): $\quad$ Fajardo Bullón, Fernando; Santos, Eduardo J. R.

Publicado por: Imprensa da Universidade de Coimbra

URL

persistente: URI:http://hdl.handle.net/10316.2/38612

DOI: $\quad$ DOI:http://dx.doi.org/10.14195/978-989-26-0775-7_8

Accessed : $\quad$ 26-Apr-2023 15:42:16

A navegação consulta e descarregamento dos títulos inseridos nas Bibliotecas Digitais UC Digitalis, UC Pombalina e UC Impactum, pressupõem a aceitação plena e sem reservas dos Termos e Condições de Uso destas Bibliotecas Digitais, disponíveis em https://digitalis.uc.pt/pt-pt/termos.

Conforme exposto nos referidos Termos e Condições de Uso, o descarregamento de títulos de acesso restrito requer uma licença válida de autorização devendo o utilizador aceder ao(s) documento(s) a partir de um endereço de IP da instituição detentora da supramencionada licença.

Ao utilizador é apenas permitido o descarregamento para uso pessoal, pelo que o emprego do(s) título(s) descarregado(s) para outro fim, designadamente comercial, carece de autorização do respetivo autor ou editor da obra.

Na medida em que todas as obras da UC Digitalis se encontram protegidas pelo Código do Direito de Autor e Direitos Conexos e demais legislação aplicável, toda a cópia, parcial ou total, deste documento, nos casos em que é legalmente admitida, deverá conter ou fazer-se acompanhar por este aviso. 


\section{INTERNATIONAL \\ STUDIES IN TIME \\ PERSPECTIVE}

MARIA PAULA PAIXÃO

JOSÉ TOMÁS DA SILVA

(COORD.)

VICTOR ORTUÑO

PEDRO CORDEIRO

(EDITORS)

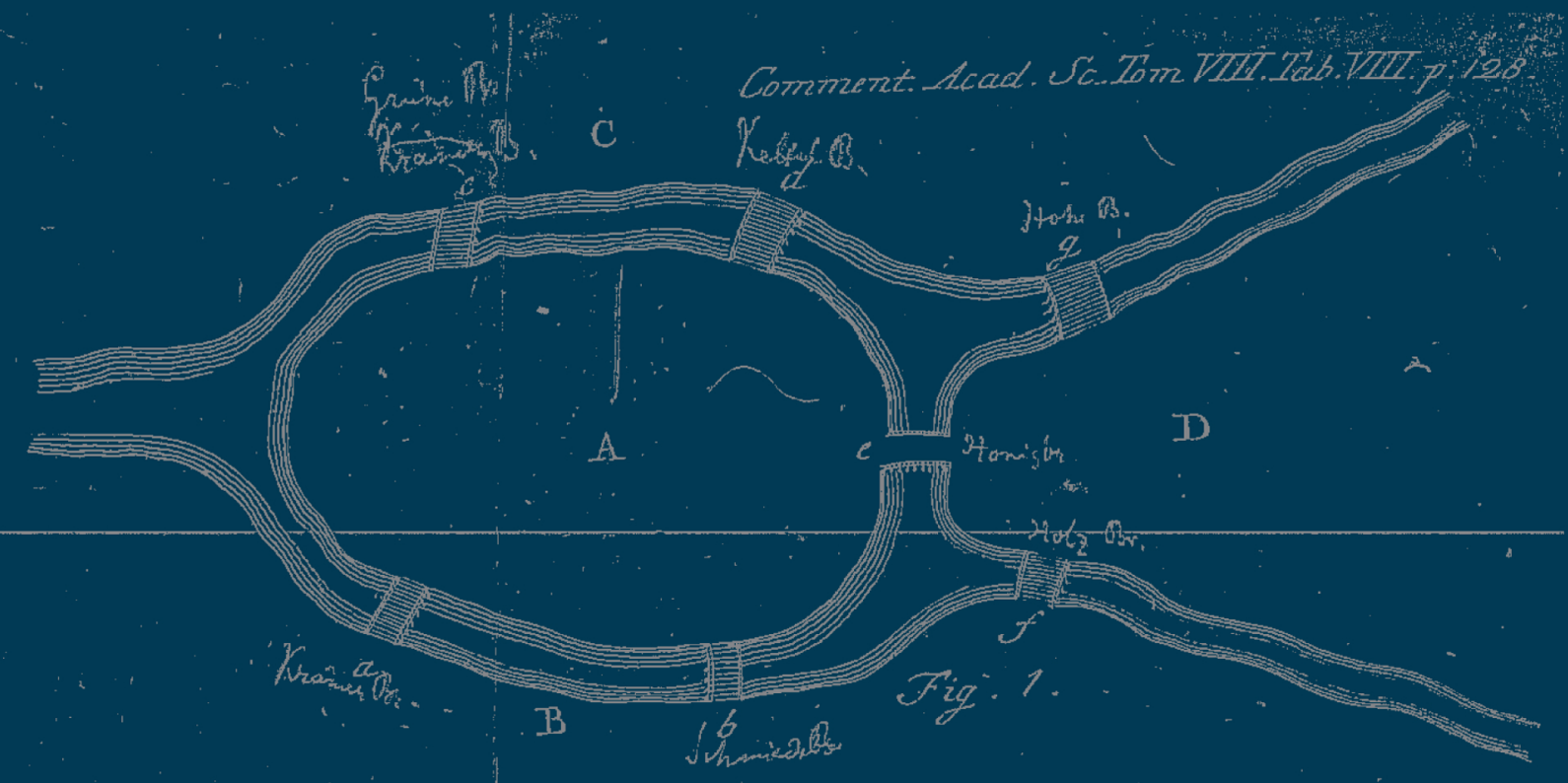

IMPRENSA DA

UNIVERSIDADE

DE COIMBRA

COIMBRA

UNIVERSITY

PRESS 


\title{
Chapter 8 \\ INFLUENCE OF EARLY STRESSFUL LIFE EVENTS ON THE FUTURE EXPECTANCY CHANGES AND CURRENT ADDICTIONS IN HOMELESS PEOPLE
}

\author{
Fernando Fajardo Bullón \\ Department of Psychology and Anthropology, Extremadura University, Spain \\ fernandofajardo@unex.es \\ Eduardo J. R. Santos \\ IPCDVS, Coimbra University, Portugal \\ eduardosantos@fpce.uc.pt
}

\begin{abstract}
Aвstract: Stressful life events experienced at an early developmental stage could have a negative influence on the rest of people's lives. For this research 49 homeless people were selected from two Spanish foster care centres. They were interviewed for three months and divided in two groups, using a Statistical Latent Classes Model, according to the following variables: number of stressful life events experienced before sixteen years old, having a current addiction and future changes expectancy. Homeless people with high probabilities of having between 1 and 5 stressful life events before sixteen, (0.704; $70.4 \%)$, had a higher probability of having a negative expectation of future changes in their lives $(0.77 ; 77 \%)$ and presented a higher probability of not having current addictions $(0.763 ; 76.3 \%)$. However, individuals with higher probability of having more than 5 stressful events $(0.662 ; 66.2 \%)$ had a higher probability of having a positive outlook about change of situation in the future $(0.758$; $75.8 \%)$ and presented a higher probability of having a current addiction $(0.614 ; 61.4 \%)$. According to these data, a relationship between past, present and future exists. Therefore, it would be advisable to anticipate addiction prevention policies or motivation therapy according to the number of stressful life events experienced before sixteen.
\end{abstract}

Keywords: homeless people, stressful life events, addiction, future expectancy.

\section{INTRODUCTION}

The year 2010 was designated as the "European Year against the Poverty and the Social Exclusion". In order to study the situation of the most disadvantaged people, a research project about the homeless people in the Spanish cities of Mérida and Badajoz was started (Fajardo, 2010). In this research, in addition to others variables, the influence of the stressful life events were analyzed.

The stressful life events are the key events in people's lives that they recognize as important in their development. It is known the association between stressful life events and the increased likelihood to present a psychopathology. Negative life events could predict the course of depression (Paykel,2003) and the presence of anxiety disorders but not the maintenance of these ones (Kendler, Hettema, Butera, Gardner, \& Prescott, 
$2003 \mathrm{~b}$ ). Stressful life events give rise to a higher probability of present depressive and anxiety symptoms, over and above the effects of age, gender, education and size of the social network, duration of last episode, positive life events and baseline symptom severity. (Paykel, 2003; Spinhoven et al, 2011).

Some research associates the occurrence of stressful events with drugs' use as a way of coping with these events and their emotional consequences (Thompson, 2004). It is essential to analyze if the stressful life events in homeless people's childhood and adolescence could be related to the higher likelihood of having a current addiction and future changes expectancy. Thus, we tried to find out specifically about the stressful events in childhood and adolescence because the childhood stressful events could lead to increased vulnerability to recent life events (Sandín, 2003). Thereby, as a person experiences more stressful life events in his/her life, the emotional impact of each of them may be higher. This way, it is essential not only to know about the stressful life events lived by homeless people, but also to provide psychological therapies by specialists to help overcome any future disorders. Therefore, the aim of this research was to analyze stressful life events experienced in homeless people before sixteen and to analyze their influence on having a current addiction and future changes expectancy.

\section{Method}

Sample and procedure. 91 homeless people were randomly selected during the months of July, August and September 2009, from a 1020 homeless people estimated population who were living during the last year in the Caritas foster care centres of Badajoz and Merida cities. The sample had a precision of 0.09 for a confidence level of $95 \%$ and in the most unfavorable conditions $(\mathrm{p}=\mathrm{q}=0.5) .49$ people were selected from the initial sample due to the specific fields researched for this particular study.

Questionnaire. In order to analyze stressful life events, the List of Threatening Events Questionaire (LTE-Q) (Brugha \& Cragg,1990) was readjusted and expanded. The LTE-Q has shown good test-retest reliability $(\mathrm{k}=0.78-1.0$ on all categories except 'something you valued was lost or stolen', where $\mathrm{k}=0.24)$, high agreement between participant and informant ratings $(\mathrm{k}=0.7-0.9)$, as well as good agreement with interview based ratings (sensitivity $=0.89$; specificity $=0.74$; Brugha $\&$ Cragg, 1990). The LTE-Q was extended with some items according to the experiences lived in the last ten years in the foster care centres and with questions about having or not having a current addiction and future changes expectancy were added.

Statistical Analysis. The 49 homeless people's data were divided into groups in the following way: item $1=$ stressful life events before sixteen $(1=$ none; $2=$ from 1 to 5 stressful events; $3=$ more than 5 stressful events). Item $2=$ having current addictions ( $1=$ yes; $2=$ no) and item 3 = future changes expectancy $(1=$ yes; $2=$ no). In the statistical model used the manifest variables and latent variables are categorical, thus we decided to use a Latent Class Model (LCM). This Model assumes that the population of individuals is divided into a number of exclusive and exhaustive latent classes, considered as categories. Accordingly each individual belongs exclusively to a latent class. 


\section{Results}

When we applied the latent class model, we identified a model with two latent classes. The estimated results are presented in the next table.

Table 1 - Characteristics of the latent class model

\begin{tabular}{|c|c|c|c|c|c|c|c|}
\hline & \multicolumn{3}{|c|}{ Latent Class 1} & & \multicolumn{3}{|c|}{ Latent Class 2} \\
\hline & \multicolumn{3}{|c|}{ Prob. Latent Class $=0.276(\mathrm{sd}=0.147)$. } & & \multicolumn{3}{|c|}{ Prob. Latent Class $=0.724(s \mathrm{~d}=0.147)$. } \\
\hline & Catg. 1 & Catg. 2 & Catg. 3 & & Catg. 1 & Catg. 2 & Catg. 3 \\
\hline Item 1 & $\begin{array}{l}0.296 \\
(0.188)\end{array}$ & $\begin{array}{l}\mathbf{0 . 7 0 4} \\
(0.188)\end{array}$ & 0.000 & Item 1 & 0.000 & $\begin{array}{l}\mathbf{0 . 6 6 2} \\
(0.101)\end{array}$ & $\begin{array}{l}0.338 \\
(0.101)\end{array}$ \\
\hline Item 2 & $\begin{array}{l}0.237 \\
(0.184)\end{array}$ & $\begin{array}{l}\mathbf{0 . 7 6 3} \\
(0.184)\end{array}$ & --.--- & Item 2 & $\begin{array}{l}\mathbf{0 . 6 1 4} \\
(0.102)\end{array}$ & $\begin{array}{l}0.386 \\
(0.102)\end{array}$ & -.---- \\
\hline Item 3 & $\begin{array}{l}0.230 \\
(0.201)\end{array}$ & $\begin{array}{l}\mathbf{0 . 7 7 0} \\
(0.201)\end{array}$ & ------ & Item 3 & $\begin{array}{l}\mathbf{0 . 7 5 8} \\
(0.106)\end{array}$ & $\begin{array}{l}0.242 \\
(0.106)\end{array}$ & ------ \\
\hline
\end{tabular}

Pearson q=1.29; (d.f.=1), $\Delta=0.256$

The two latent classes model was accepted according to the Pearson contrast. As we can see in table 1 , the homeless people had a probability of $0.276(27.6 \%)$ of belonging to the latent class number 1 and a probability of $0.724(72.4 \%)$ of belonging to the latent class number 2 .

The homeless people who belonged to the latent class number 1 had a higher probability of having between 1 and 5 stressful life events $(0.704 ; 70.4 \%)$, a high probability of not having a current addiction $(0.763 ; 76.3 \%)$ and a high probability of having negative expectation of future changes in their lives $(0.77 ; 77 \%)$. In contrast, homeless people who had a high probability of belonging to the latent class 2, presented a high likelihood of having more than 5 stressful life events $(0.662 ; 66.2 \%)$, a high probability of having a current addiction $(0.614 ; 61.4 \%)$ and a high future changes expectancy $(0.758 ; 75.8 \%)$.

\section{Conclusions ANd Discussion}

It has been proved that those people who experienced between 1 and 5 stressful life events before sixteen do not have a current addiction, but have a negative expectation of future changes in their lives. This shows that these stressful events do not necessarily cause current addictions but might eventuality cause great despair. One possible explanation resides in the association between stressful life events and the presence of depressive disorders that could be related at the same time to the negative perception of future changes (Kim, Conger, Elder \& Lorenz, 2003; Kraaij et al. 2003). 
Moreover, those homeless people, who had more than 5 stressful life events had a higher probability of having a current addiction. These data agree with previous research that confirms the relationship between these events and the higher probability of substance use (Martínez, Fuertes, Ramos \& Hernández, 2003). These results, coupled with the possible risk expossure of homeless people when they were in the adolescent stage, demonstrate that it is possible that an overload of negative events adversely affects the ability to cope with these events and prevent an effective response to stress. According to our results, that effects increases the probability of starting with substance use in an attempt to escape from the situation (Jiménez, Méndez \& Hidalgo, 2008, Fajardo, 2011). Even so, these homeless people have a positive outlook about the change of the situation in the future, although they might turn to substance observe in a high percentage.

A possible solution for this population might reside in the prevention of the stressful life events and substance use through preventive interventions in the household, where parents could se trained in the basic abilities that support their children at both the infancy and adolescence stages (Lochman \& Steenhoven, 2002). This way, the emotional attachment could be improved in order to create safe emotional bases that could be useful to cope with the stressful situations in the future as well as in the development of resilience (Gómez, Thompson, \& Barczyk, 2010).

Acknowledgments. This research has been supported with the financial aid of Cáritas Spain, Mérida and Badajoz Diocesan Cáritas, Merida and Badajoz Municipalities and the Equality and Employment Department of Junta de Extremadura.

\section{REFERENCES}

Brugha, T. S. \& Cragg, D. (1990). The list of threating experiences: the reliability and validitay of a brief life events questionnaire. Acta Psychiatr Scand, 82, 77-81.

Fajardo, F. (2010).Historias a la intemperie. Estudio de la situación de las personas sin hogar en Mérida y Badajoz. Cáritas Española Editores.

Fajardo, F (2011). Poliadicción y edad de inicio en el consumo de drogas en personas sin hogar. Revista Española de Drogodependencias, 4, 393-402.

Gómez, R, Thompson, S. J. \& BarczyK, A. N. (2010). Factors associated with substance use among homeless young adults. Subst Abus, 31(1), 24-34.

Jiménez, L., Menéndez, S. \& Hidalgo, M. V. (2008). Un análisis de los acontecimientos vitales estresantes durante la adolescencia. Apuntes de Psicología, 26(3), 397-527.

Kendler, K. S., Gardner, C. O. \& Prescott, C. A. (2003). Personality and the experience of environmental adversity. Psychol Med, 33, 1193-1202.

Kendler, K. S., Hettema, J. M., Butera, F., Gardner, C. O., \& Prescott, C. A. (2003b). Life events dimensions of loss, humiliation, entrapment, and danger in the prediction of onsets of major depression and generalized anxiety. Arch Gen Psychiatry, 60, 789-796.

Kim, K. J., Conger, R. D., Elder, Jr., G. H., \& Lorenz, F. O. (2003). Reciprocal influences between stressful life events and adolescent internalizing and externalizing problems. Child Development, 74, 127-143. 
Kraaij, V., Garnefski, N., De Wilde, E. J., Dijkstra, A., Gebhardt, W., Maes, S., \& Doest, L. (2003). Negative life events and depressive symptoms in late adolescence: Bonding and cognitive coping as vulnerability factors? J Youth Adolesc, 32, 185-193.

Lochman, J. E. \& Van den Steenhoven, A. (2002). Family-based approaches to substance abuse prevention. J Prim Prev, 23, 49- 114.

Martínez J. L., Fuertes, A., Ramos M., \& Hernández A. (2003).Consumo de drogas en la adolescencia: importancia del afecto y de la supervisión parental. Psicothema, 15(2), 161-166.

Paykel, E. S. (2003). Life events and affective disorders. Acta Psychiatr Scand,108, 61-66.

Spinhoven, P., Roelofs, K., Hovens, J., Elzinga, B., Van Open, P., Zitman, F. \& Penninx, B.(2011). Personality, Life events and the Course of Anxiety and Depression. Eur.J.Pers. 25, 443-452.

Thompson, S. J. (2004). Risk/protective factors associated with substance use among runaway/ homeless youth utilizing emergency shelter services nationwide. Subst Abus, 25(3),13-26. 